DOI: $10.2478 / \mathrm{v} \cdot 10169-012-0018-8$

\title{
APPLICATION OF ADHESIVE BONDING IN STEEL AND ALUMINIUM STRUCTURES
}

\author{
M. PIEKARCZYK ${ }^{1}$, R. GREC ${ }^{2}$
}

\begin{abstract}
The paper presents achievements in gluing technique in steel and aluminium structures. Adhesives currently in use and available on the market are characterized from the point of view of their mechanical properties. Design rules of adhesive connections and basic methods for their calculations are mentioned. The most significant examples of the applications of those joints in steel as well as aluminium structures are shown.
\end{abstract}

Key words: steel structures, aluminium structures, gluing technique, connections.

\section{INTRODUCTION}

The idea of applying adhesive bonding to metals had its origins in the adaptation of phenolic adhesives used initially for bonding of wood as well as in the introduction of rubber-metal joints in machinery. In 1942, the phenol formaldehyde modified adhesive - Redux 775, with powder improver of methyl polyvinyl, which raises the strength of the adhesive and its resistance to environmental influences, was applied for the first time in the air industry to combine metal parts. This adhesive has been used in the construction of aircraft (Fokker 100) until today, Dillard [1].

The breakthrough in metal bonding was caused by the introduction of epoxy resins by the Swiss company CIBA in 1946. They were mainly applied in aerospace engineering, in particular after the development of etching technique to joined surfaces by means of chromic acid.

An example of the successful application of adhesives in building structures is the steel bridge over the Lippe-Seiten channel near Marl in Germany. It is the first "glued" bridge where adhesive bonding is backed up by bolts in case of adhesive bonding failure. The bridge was built in 1950 and was used till 2001 without any damage. The second example is a "glued" bridge over the same channel built in 1963, Meinz [2].

\footnotetext{
${ }^{1}$ Department of Civil Engineering, Cracow University of Technology, Warszawska Str. 24, 31-155 Cracow, Poland

2 Department of Civil Engineering, Cracow University of Technology, Warszawska Str. 24, 31-155 Cracow, Poland, e-mail: grec@pk.edu.pl
} 
Adhesive bonding has been in regression since the end of the nineteen sixties of the last century because of rapid advances in welding technique. Nowadays, adhesive bonding is becoming more increasingly important as a means of strengthening, Kubieniec [3], Kubieniec, Piekarczyk [4], Pasternak, Kubieniec, Piekarczyk [5], Pasternak, Meinz [6] and connecting, Dilger, Feldman, Gei $\beta$, Pasternak, Ummenhofer [7], Feldman, Volling, Ge $\beta$ ler, Wellershoff, Gei $\beta$, Wagner [8], Król [9], Meinz [2], Pasternak, Schwarzlos, Schimmach [10] light gauge as well as slender steel and aluminium structures. Adhesives are also used successfully to join metal parts with glass in the modern architectural objects, mainly elements of façades CwYL [11], MachaLicKa, Eliasowa [12], Pasternak, Meinz [13].

Adhesive bonding techniques in metal structures have also been developed for years by Polish scientists, in particular in the Air Institute of Aviation Technology in Military University of Technology by J. Godzimirski and colleagues, listed here only since 2004, Godzimiński, Tкaczuk [14], [15], Godzimiński, Komorek [16], Godzimiński, Rośкоwicz [17].

Special attention should be paid to M. Lagoda who in his monograph [18] presented a method of strengthening steel bridges by elements joined with adhesives. The conclusions derived from many years of practice and confirmed experimentally in that study show that adhesive joints are effective in this field from economical and technical point of view.

In recent years, studies on the application of the adhesive techniques in steel structures have been carried out in Warsaw University of Technology mainly by W. Żółtowski regarding connecting of façade elements, Żółtowski, CwYL, KróL [19], and in Cracow University of Technology in the field of strengthening slender girders by adhesively joined steel elements, Kubieniec [3], Kubieniec, Piekarczyk [4], [20], Pasternak, Kubieniec, Piekarczyk [21].

Nowadays also another technology of strengthening building elements i.e. with use of external carbon fiber reinforced polymer ( CFRP) strips bonded to them by adhesives, developed previously in concrete constructions e.g. GŁodKowsкa, Ruchwa [22], Urban, Tarka [23], is in constant progress in steel slender structures Peiris, Harik [24].

Aluminium structures may also be connected by adhesive bonding, mainly in joining secondary elements in aerospace industry [25], in shipbuilding and in automotive industry, HiLL [26]. In construction adhesive bonding is used to connect external panels of façades [27]. Examples of the application are given in chapter 5.5. 


\section{Types of GLUES IN METAL STRUCTURES AND THEIR BASIC PROPERTIES}

\subsection{Classification and types of adhesive bonding}

Classification of adhesives can be made on the basis of various criteria, e.g. basic chemical components (inorganic, organic, natural organic, synthetic organic); consistency (liquid, plastic, solid) and hardening (chemical hardening, hybrid, physical hardening Feldman, Volling, Ge $\beta$ Ler, Wellershoff, Gei $\beta$, Wagner [8]).

In addition to the glues already mentioned in the introduction, two compound adhesives hardened by polymerization have gained the greatest importance in metal structures. Two compound adhesives are based on polyesters, acrylic or vinylester, in particular epoxy and polyurethane glues as well as one compound polyurethane adhesives. The adhesives shown in the Table 1 are the examples of the aforesaid adhesives according to the data available in German documents Dilger, Feldman, Gei $\beta$, Pasternak, Ummenhofer [7], Meinz [2]. They are also presented in Fig. 1 to show a relation between their elastic and plastic properties and the chemical composition.

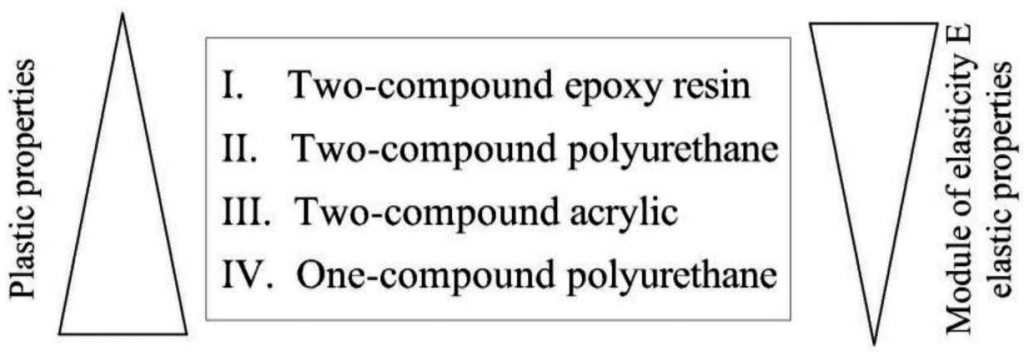

Fig. 1. Elastic and plastic properties of adhesives according to Table 1.

Polish market also offers a wide range of metal oriented adhesives of high endurance, for example Proxima adhesives produced by NTR company from Bełchatów [28] as well as the adhesives produced by Megachemie (Cracow) [29], see Table 3.

Information available in this field is very complex.

\subsection{Mechanical PRoperties of adHesives}

The design of adhesive connections is based on the knowledge of the fundamental mechanical characteristics of adhesives i.e.: shear strength $\mathrm{R}_{t}$, tensile strength $\sigma_{z a}$, modulus of elasticity $\mathrm{E}_{a}$ and shear modulus $\mathrm{G}_{a}$ (see Table 1).

Shear strength $\mathrm{R}_{t}$ is specified with the use of a specimen consisting of two lap joined metal plates as for example in Fig. 2, Kubieniec [3] in a tensile machine at constant speed until failure of the connection. The test is described in the standard PN-69/C-893000 [30]. 


\begin{tabular}{|c|c|c|c|c|c|c|c|c|}
\hline 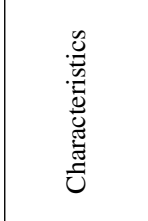 & 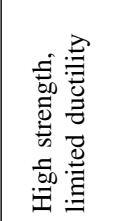 & 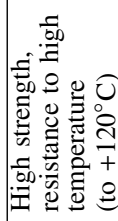 & 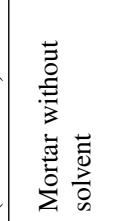 & 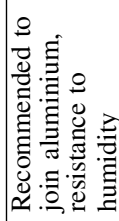 & 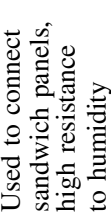 & 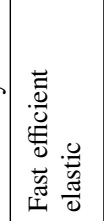 & 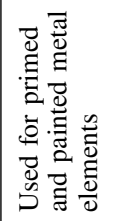 & 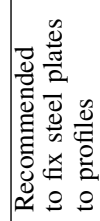 \\
\hline 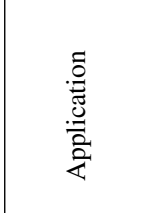 & 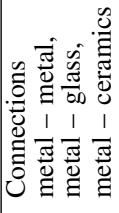 & 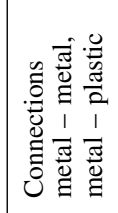 & 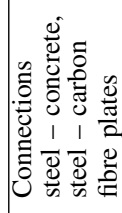 & 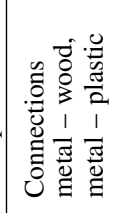 & 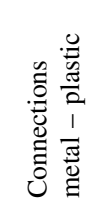 & 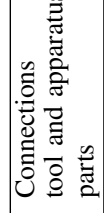 & 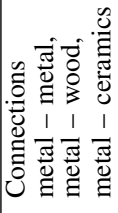 & 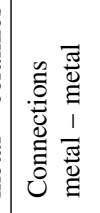 \\
\hline 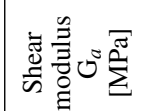 & in & 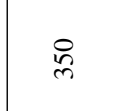 & হু & 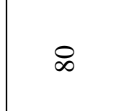 & q & 8 & $n$ & $\begin{array}{c}\substack{c \\
\infty \\
\infty \\
\infty} \\
\stackrel{\infty}{n}\end{array}$ \\
\hline 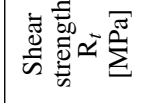 & $\pi$ & $\stackrel{N}{\circ}$ & $\bar{m}$ & $=$ & $\stackrel{?}{?}$ & n? & $\stackrel{\sim}{\Im}$ & ה \\
\hline 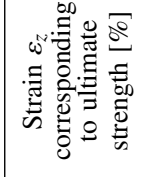 & $\vec{i}$ & $\stackrel{n}{m}$ & â & $\stackrel{\circ}{i}$ & $\stackrel{̊}{\mathrm{I}}$ & : & $\stackrel{8}{8}$ & ¿̊. \\
\hline 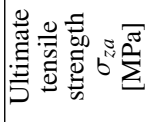 & $\stackrel{\text { ते }}{ }$ & $\stackrel{\circ}{\dot{m}}$ & 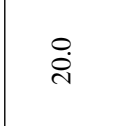 & $\stackrel{\circ}{\dot{I}}$ & $\stackrel{\circ}{\mathrm{I}}$ & $\stackrel{n}{m}$ & $\stackrel{\circ}{-}$ & $\stackrel{\infty}{-}$ \\
\hline 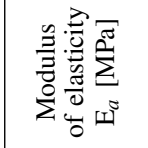 & $\frac{8}{N}$ & 足 & $\underset{8}{\&}$ & $\stackrel{\infty}{\stackrel{\infty}{\sim}}$ & 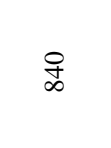 & 5 & $\vec{i}$ & $\stackrel{m}{=}$ \\
\hline 莡 & 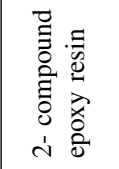 & 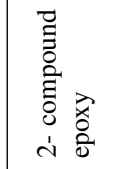 & 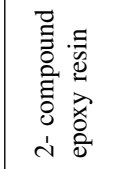 & 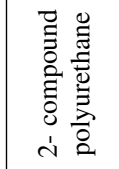 & 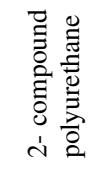 & 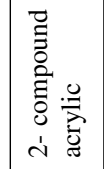 & 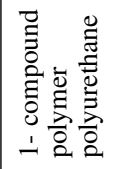 & 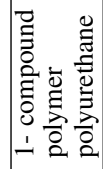 \\
\hline 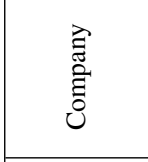 & 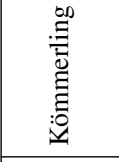 & $\sum_{\text {N }}^{\Sigma}$ & $\frac{\tilde{w}}{5}$ & 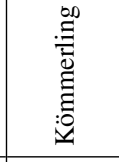 & 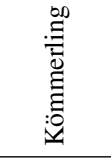 & 㺃 & 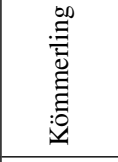 & 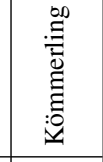 \\
\hline 鴶 & 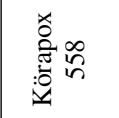 & 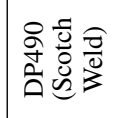 & 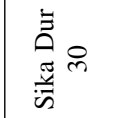 & 言。 & 言芯 & 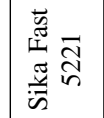 & 言总昌 & 递 \\
\hline$\stackrel{\dot{g}}{1}$ & - & N & $m$ & + & in & 0 & r & $\infty$ \\
\hline $\mathrm{I} \cdot \mathrm{s} ! \mathrm{t}$ & \multicolumn{3}{|c|}{-} & \multicolumn{2}{|c|}{$=$} & B & \multicolumn{2}{|c|}{$z$} \\
\hline
\end{tabular}




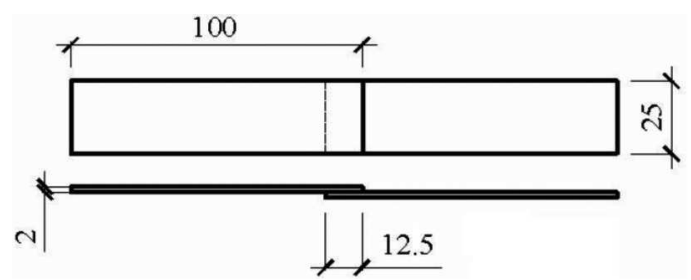

Fig. 2. Geometry of a specimen in shear strength tests of an adhesive after [30] (Kubieniec [3]).

The Polish standard [30] cannot serve as a basis how to describe the relation between shear stress $\tau$ and angular deflection $\gamma$ or slip $(\tan \gamma)$ and how to describe shear module $\mathrm{G}_{a}$. Those descriptions are presented in German standards, e.g. DIN EN ISO/DIS 11003 (2) [31]. Specimens, a compound of two plate bars joined by a thin layer of glue as shown in (Fig. 3, KubiENIEC [3]), shall be placed in a tensile machine and loaded till rupture.

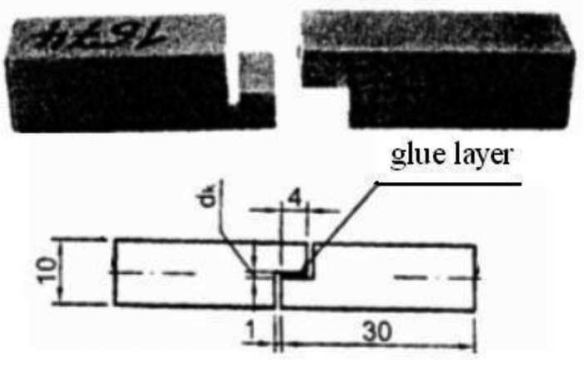

Fig. 3. Shape of a specimen in shear tests after [31] (Kubieniec [3]).

The ultimate tensile strength $\sigma_{z a}$ and the modulus of elasticity $\mathrm{E}_{a}$ can be specified by the Polish standard PN-81/C-89034 [32] or for example the German code DIN EN 26922 [33]. In this study, KUBIENIEC [3], tensile tests were carried out on specimens according to [32] as shown in Fig. 5 whereas in, Meinz [2], on specimens according to [33] shown in Fig. 6.

The values of the mechanical characteristics obtained in the above mentioned tests are given for various adhesives in Table 1.

\subsection{EFFECT OF TEMPERATURE ON MECHANICAL PROPERTIES}

Mechanical properties of polymers are strongly dependent on the temperature and undergo degradation with its elevation.

The change of maximum normal stress-longitudinal strain behaviour in dependence on the testing temperature for a two-compound epoxy pre-polymer, Feldman, Volling, Ge $\beta$ Ler, Wellershoff, Gei $\beta$, Wagner [8] is given in Table 2. 


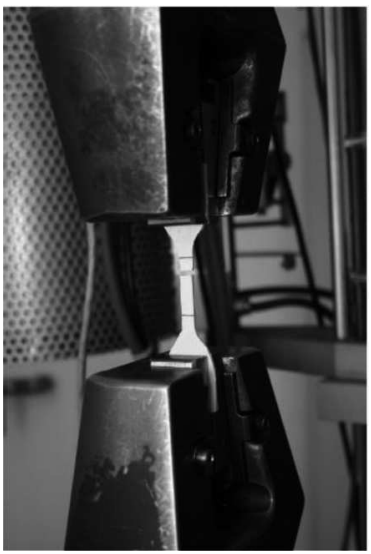

Fig. 4. Tensile test. failure of a specimen after [32] (KubIENIEC [3]).

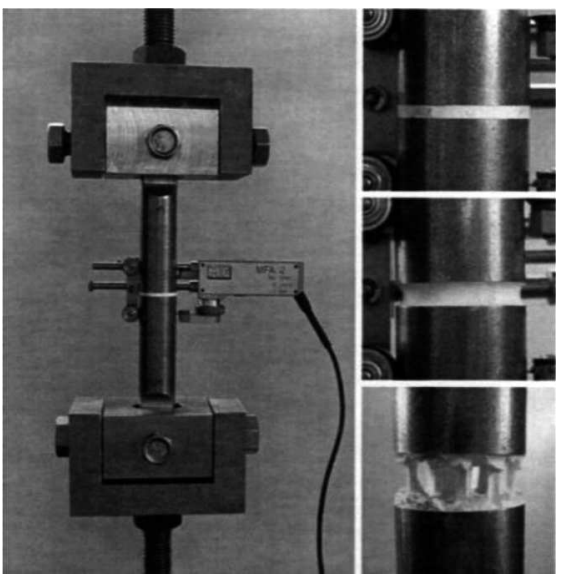

Fig. 5. Tensile test for an adhesive specimen after [33] (Meinz [2]).

Table 2

Mechanical properties of an epoxy glue in various temperatures.

\begin{tabular}{|c|c|c|}
\hline Temperature & $\begin{array}{c}\text { Ultimate strength } \\
\sigma_{z a}[\mathrm{MPa}]\end{array}$ & $\begin{array}{c}\text { Corresponding strain } \\
\varepsilon[\mathrm{mm} / \mathrm{mm}]\end{array}$ \\
\hline$-40^{\circ}$ & 25 & 0.006 \\
\hline$-10^{\circ}$ & 42 & 0.013 \\
\hline $23^{\circ}$ & 53 & 0.024 \\
\hline $50^{\circ}$ & 42 & 0.025 \\
\hline $80^{\circ}$ & 30 & 0.025 \\
\hline $120^{\circ}$ & 2 & 0.025 \\
\hline
\end{tabular}


An important parameter in assessing the suitability of a glue to be applied at high temperatures is glass transition temperature $\left(\mathrm{T}_{g}\right)$, in which the resin begins to soften and its mechanical properties are degraded. Table 3 presents typical ranges of glass temperature for various construction adhesives.

Table 3

Glass transition temperatures for constitutional adhesives.

\begin{tabular}{|c|c|c|c|}
\hline I.n. & Type of adhesive & $\begin{array}{c}\text { Trademark } \\
\text { [28], [29], [34] }\end{array}$ & $\begin{array}{c}\text { Glass transition } \\
\text { temperatures } \mathrm{T}_{g}\left[{ }^{\circ} \mathrm{C}\right]\end{array}$ \\
\hline 1 & Anaerobic & $\begin{array}{l}\text { Monolith } \\
\text { MH 745-3 } \\
\text { MH 525-3 } \\
\text { MH 995-3 }\end{array}$ & $150^{\circ}-200^{\circ}$ \\
\hline 2 & Cyanate-acrylate & $\begin{array}{l}\text { Monolith } \\
\text { CM 30-3 } \\
\text { CM 70-3 }\end{array}$ & $95^{\circ}$ \\
\hline 3 & Two-compound methacrylate & MA & $170^{\circ}$ \\
\hline 4 & Two-compound epoxy & $\begin{array}{l}\text { Monolith EP } \\
\text { EP 2523-1 } \\
\text { EP 2523-2 } \\
\text { EP 2523-1 } \\
\text { EP 2523-2 }\end{array}$ & $250^{\circ}$ \\
\hline 5 & Two-compound polyurethane & - & $190^{\circ}$ \\
\hline 6 & $\begin{array}{l}\text { Two-compound modified } \\
\text { epoxy resin }\end{array}$ & Neopoxe 30 & $51^{\circ}$ \\
\hline
\end{tabular}

As it is shown in Table 3, manufacturers constantly improve adhesive properties $\left(\mathrm{T}_{g}\right)$ at elevated temperature.

\section{PRINCIPLES OF THE USE OF AdHESIVES}

\subsection{Selection of an ADHESIVE}

The selection of an adhesive should be based on the following factors: type of surfaces to be joined (e.g. galvanized or not), exposure to corrosion(e.g. humidity, salinity), behaviour of the connection at low or elevated temperatures (below- $30^{\circ} \mathrm{C}$ and above $90^{\circ} \mathrm{C}$ ), complexity of connections, cost (in particular compared to welding), mechanical properties, shrinkage, creep, resistance to ageing, CzARnoRmsKa [35], mostly according to the manufacturer's recommendations (see Table 1 - column: application).

\subsection{Assembling TECHNOLOGY OF ADHESIVE BONDING}

The assembling technology of adhesive bonding includes, Hop [36]: surface treatment, preparation of an adhesive, priming of surfaces (if necessary), application of the glue, initial drying of the glue (if necessary), merging using proper pressure, curing of the 
adhesive and conditioning of the connection, finishing of the connection (if needed to be primed, Czarnormska [35]), control of the connection.

Special surface treatment of joined parts is of great importance for the strength and the resistance of connections. The requirements are established mainly by the producer of the adhesive, e.g., Dillard, Feldman, Geiss, Pasternak, Ummenhofer [7], Fig. 6 presents an overview of surface treatment methods for aluminium alloys, Dillard [1].

For structural steel, good results are obtained using abrasion or brushing, e.g. grit blasting treatment with cleaning with dry air. Thin elements could be treated with nitrogen-phosphoric acids.

Treatment of stainless steel and chrome steel requires the use of chemical or electrochemical processes with acid etching and mechanical treatment. The last achievement in this area is to use sol -gels by Boeing. Mechanically cleaned surfaces are treated with sol, which is a mixture of silane (siliconmethane) glycidoxyl acid and zirconate alcoxide. On the surface of the metal, a thin layer is created which is also active in the merger of epoxy primer. Sol-gel is available on the market as AC-130, manufactured by AC TECH, Dillard [1].

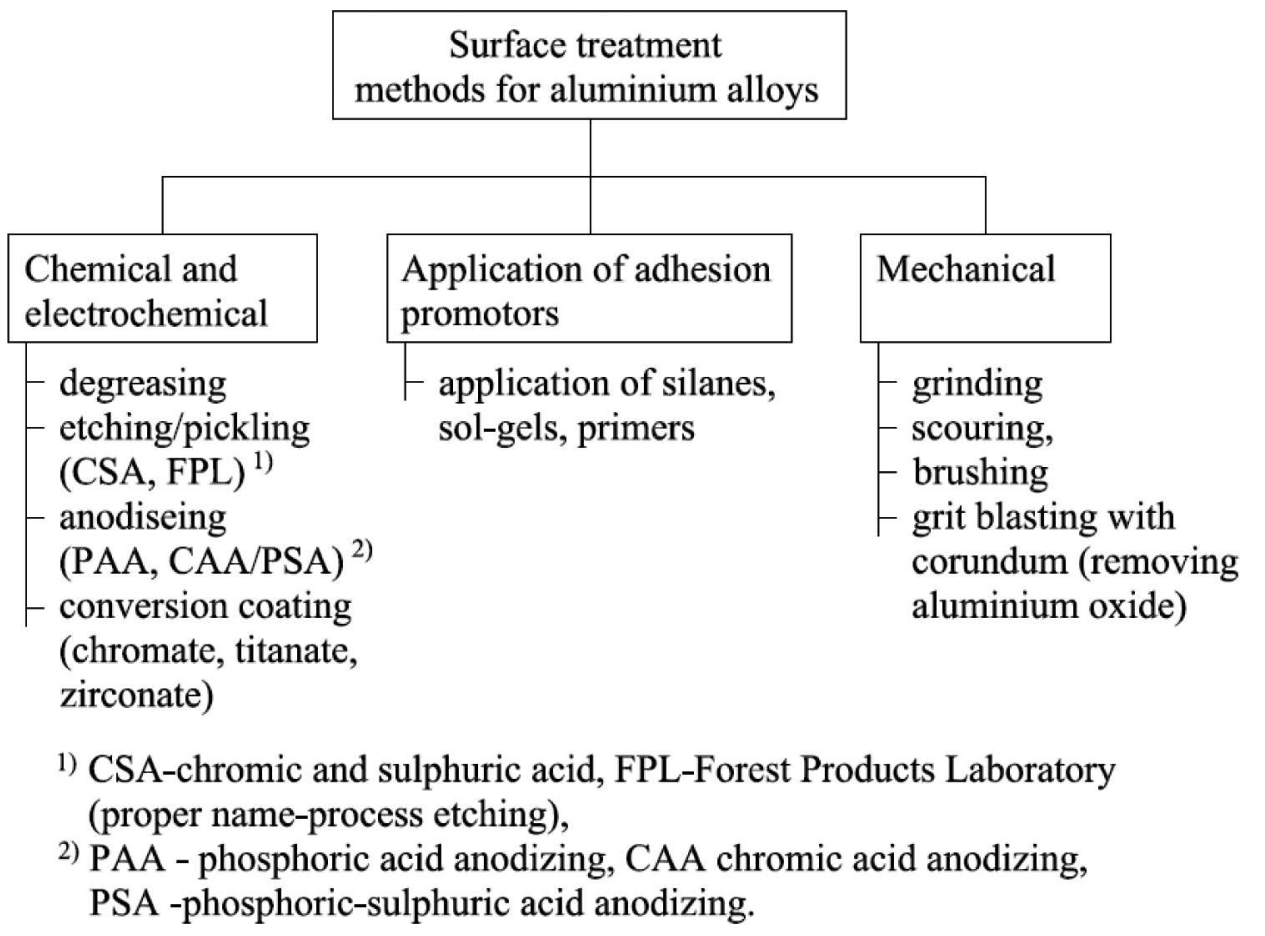

Fig. 6. Surface treatment methods for aluminium alloys, DiLLaRd [1]. 


\subsection{GeNERAL RULES FOR DESIGNING ADHESIVE BONDING}

In the design of adhesive bonded structures, it is necessary: to ensure sufficient surface to bear loads, to avoid rupture and tear loads (see Fig. 7), to replace tensile stresses with compressive ones (see Fig. 7), to avoid stress concentrations by proper construction of a joint (see Fig. 8).

\begin{tabular}{|l|l|l|l|}
\hline \multicolumn{2}{|c|}{ Equally distributed stresses } & \multicolumn{2}{c|}{ Non-equally distributed stresses } \\
\hline $\begin{array}{l}\text { Shear } \\
\text { "favourable" }\end{array}$ & $\leftrightarrow$
\end{tabular}

Fig. 7. Advantageous and disadvantageous loading on adhesive joints, MeInz [2].

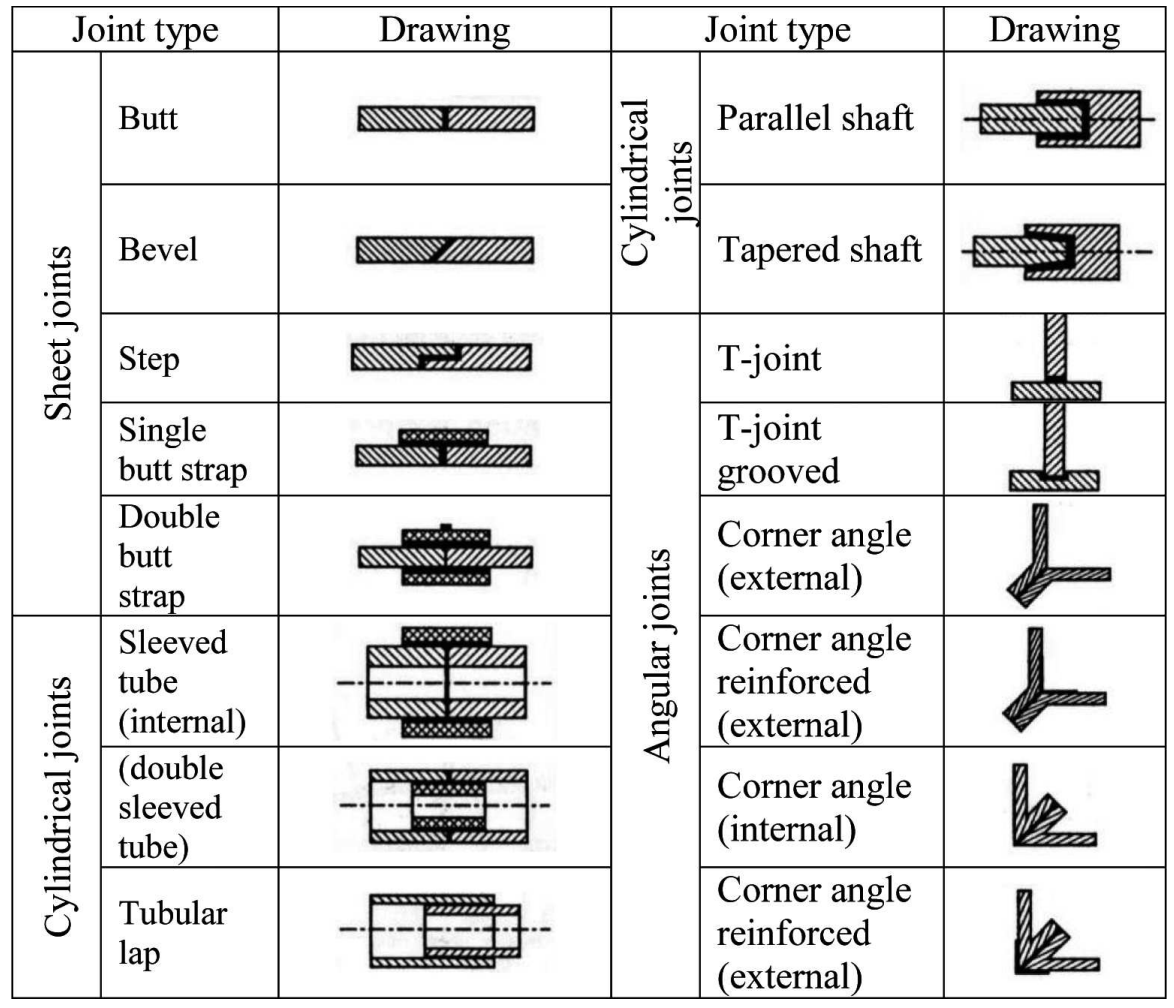

Fig. 8. Choice of appropriate connections and gluing technique after Dillard [1]. 


\section{Design METHODS For ADHESIVE CONNECTIONS}

\subsection{Analytical solutions}

Complete analytical solutions have been reached in selected cases of geometry and loading of connections with many simplifications. In particular, such solutions are known for:

- lap joints (Volkeresen [37], Tsai, Oplinger, Morton [38]),

- lap joints with bending (Goland, Reissner [39], Tsai, Oplinger, Morton [38]),

- eccentrically loaded lap joints with a variable tensile force (Kim and Kedward [40]),

- lap joints loaded parallel to the width (Hart-Smith [41], KIm and Kedward [40]),

- double lap joints (De Brugne [42], Tsai, Oplinger, Morton [38]),

- double lap joints with stresses in elastic-plastic range taking into account thermal properties (Hart-Sмith [43]),

- double lap joints with stresses in elastic-plastic range and determining the carrying capacity of the joint (Davis, Bond [44], Hart-Smith [43]).

\subsection{NUMERicAl METHODS}

Finite element method allows to model glued connections in 3D space taking into account elastic-plastic behaviour of the adhesive and the joined elements. FEM method is growing in popularity Dillard [1], Kubieniec [3], Kubieniec, Piekarczyk [4], Meinz [2], Pasternak, Kubieniec, Piekarczyk [5] but requires a good knowledge of the rules to create a model and carry out an analysis regarding optimization of grid density in the selected areas.
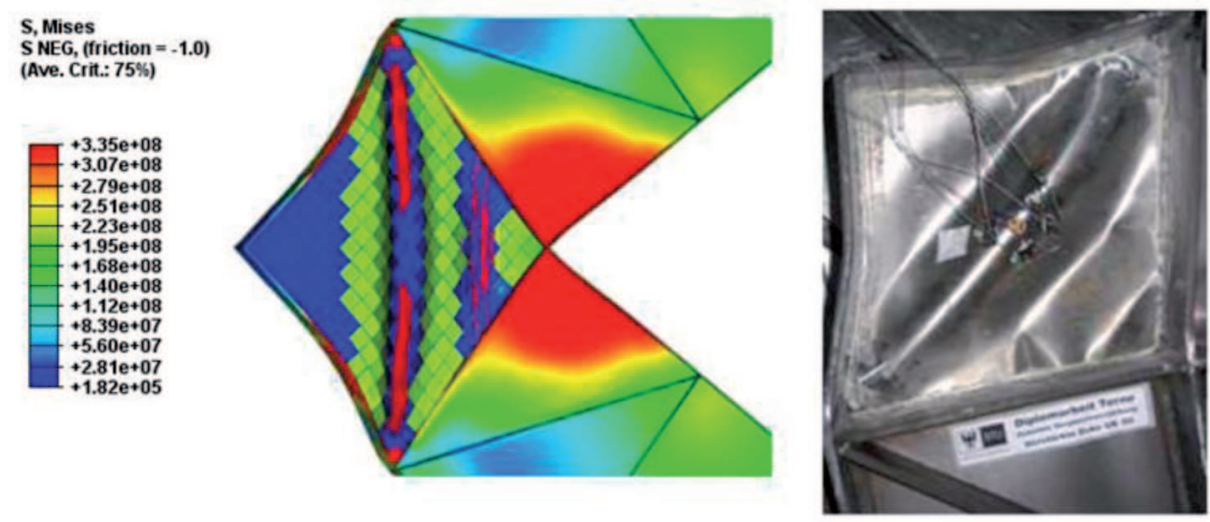

Fig. 9. Numerical (ABAQUS) and experimental models of a reinforced knee joint of a frame in the phase of failure Pasternak, Kubieniec, Piekarczyk [5], [21]. 
The numerical solutions obtained with use of FEM commercial programs such as ANSYS, ABAQUS or DIANA become certain after positive verification with the results of suitable experimental tests as it is shown for example in the Fig. 9 for a stiffened knee joint of a frame from a plate girder and in Fig. 10 for a stiffened box girder (compare chapter 5.3), Pasternak, Kubieniec, Piekarczyk [5], [21].

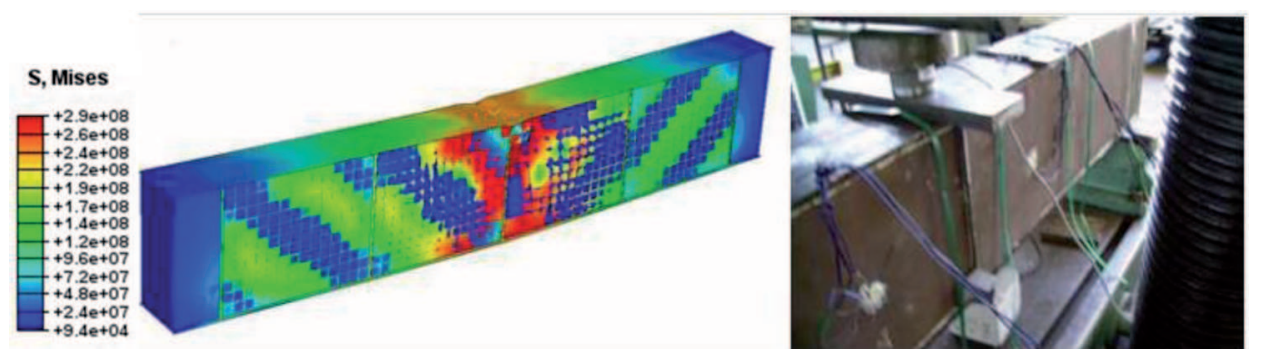

Fig. 10. Numerical (ABAQUS) and experimental models of a reinforced box - girder in the phase of failure Pasternak, Kubieniec, Piekarczyk [5], [21].

\subsection{HANDBOOK AND STANDARD APPROCHES}

For engineering purposes, the rules that are included in standards or expert guidances are used to design connections fast and safely. Several authors have concluded, CWYL [11], Kubieniec [3], Meinz [2] that there have been no rules in this field in Eurocodes yet, they are only in the phase of creation, Pasternak, Ciupak [45]. There are however a number of precise studies as to how to design some selected structures, e.g. glass façades fastened with glues to metal frames CLARK [46], [47] or thin gauge elements adhesively bonded, de Brugne [42], [48], Habenicht [49], [50]. In addition, some elaborations have been created to verify the different connection types, most of which are presented in this study.

\section{EXAMPLES OF APPLICATION OF ADHESIVE CONNECTIONS IN METAL STRUCTURES}

\subsection{FaÇADES ON METAL FRAMEWORKS}

Glass façades are the type of structures in which the technique of adhesive bonding (mainly with silicon glue) have been used successfully to improve the aesthetics, lightness and transparency of the structures Cwyl [11], Dilger, Feldman, Gei $\beta$, Pasternak, Ummenhofer [7], Machalicka, Eliasova [12], Meinz [2], Pasternak, Meinz [13], ŻóŁTOWSKI, CwYL, KRóL [19]. Façades which are not affected by a long-term static load but only by self weight and a short-term wind load give a wide scope of application of the 
adhesive for attachment Cwyl [11], Dilger, Feldman, Gei $\beta$, Pasternak, Ummenhofer [7], Machalicka, Eliasova [12], Meinz [2], Pasternak, Meinz [13].

This study, MeINz [2], offers some new possibilities of forming folded sheet façades which are glued to metal framework.

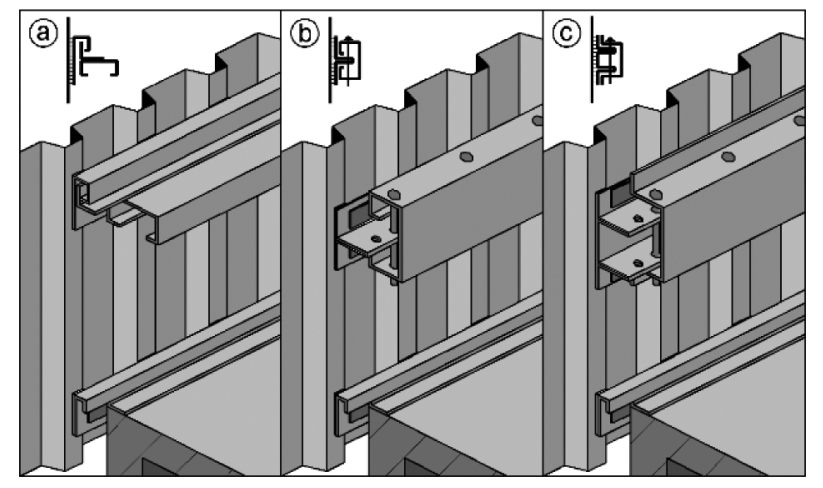

Fig. 11. Alternative ways of bonding of the folded sheet façades to the skeleton with use of adhesives, MeINZ [2].

Fig. 11 shows three ways of fastening trapezoidal sheet façades to the steel skeleton. In the variants b) and c) mechanical connectors are applied to attach the beam while in the variant a) pure adhesive connection is used. In these connections, more ductile adhesives like an acrylic glue and polyurethan are recommended rather than epoxy adhesives. The analysis conducted in the study CwYL [11] showed that the metal-glass façades with adhesive connections behave properly at temperatures from $-25^{\circ} \mathrm{C}$ up to $+90^{\circ} \mathrm{C}$ even at variable loads. They are, however, sensitive to the velocity of load change and hidden defects in the material, e.g. air bladders. Practice has shown that such connections are durable even up to 30 years.

\subsection{COLD FOLDED PROFILES AND THEIR STRENGTHENING}

Façades of modern buildings are usually supported by beam-column structures as shown below in Fig. 12, Meinz [2].

The cold formed column shown in detail (Fig. 12) is strengthened with a $2.5 \mathrm{~mm}$ thick steel plate bonded to it with an adhesive. This solution reduced slenderness of the column profile and decreased its deformations thus making it possible to use larger glass panels. The conclusions presented in the study MeINz [2] show that the degree of strengthening of the profile should not exceed $10 \%$ of its initial area in the case of unilateral strengthening shown in Fig. 12.

Some examples of cold formed adhesively bonded structures are given in the work, Pasternak, Schwarzlos, Schimmach [10]. The results of the crash test shown in Fig. 13 for double hat sections joined in pairs by powder welding (left) and gluing (right) 


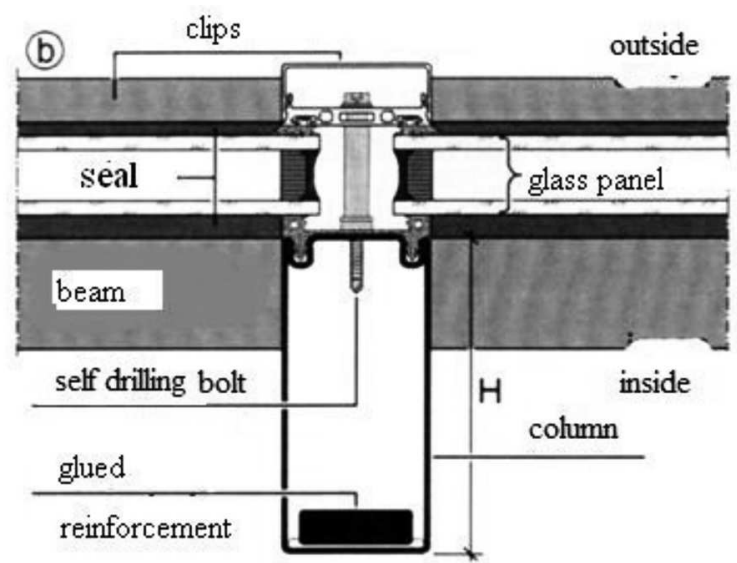

Fig. 12. Example of a beam-column supporting system of a façade - structural details, Meinz [2].

indicate a greater possibility of energy dissipation in the latter case. Furthermore, tests carried out with strut elements made from double-hat profiles $1.0 \mathrm{~mm}$ and $1.5 \mathrm{~mm}$ thick joined by adhesive ended up in failure because of loss of local stability but not of the capacity of bonding.

Another experiment conducted this time on a strengthened cold formed channel profile shown in Fig. 14 indicated a definite increase in capacity of the beams with such strengthening in contrast to the non-strengthened one from 7 to $8.5 \mathrm{kN}$. The adhesive bonded without any failure.
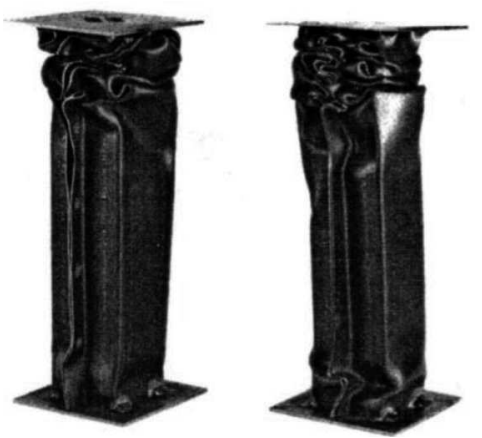

Fig. 13. Crash-tested double hat- profile, Pasternak, Schwarzlos, Schimmach [10].

\subsection{Plate girders AND their STRENGTHENing}

Plate girders with very slender webs are susceptible to local buckling which limits their bending resistance. When other methods of reinforcement, e.g. welding that destroys 


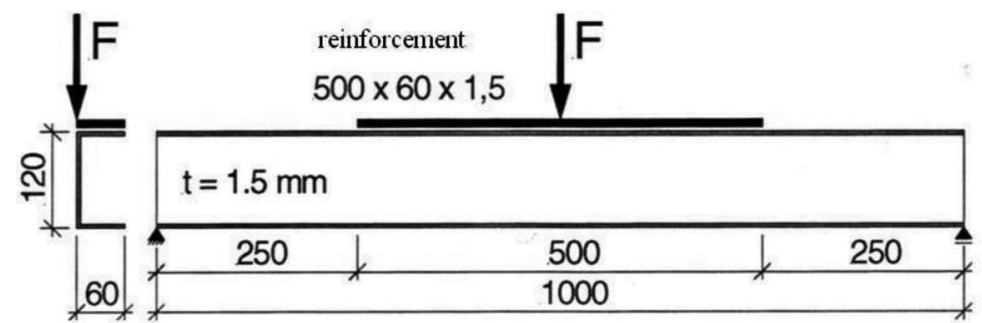

Fig. 14. Test arrangement for a reinforced beam from U profile, Pasternak, Schwarzlos, Schimmach [10].

galvanized layer or heats the plate locally too much cannot be used, adding metal plates to the web and joining the elements by adhesive bonding becomes an alternative way of structure refurbishment. It results in visible web strengthening PasternaK, KubIENIEC, Piekarczyk [5], [21].

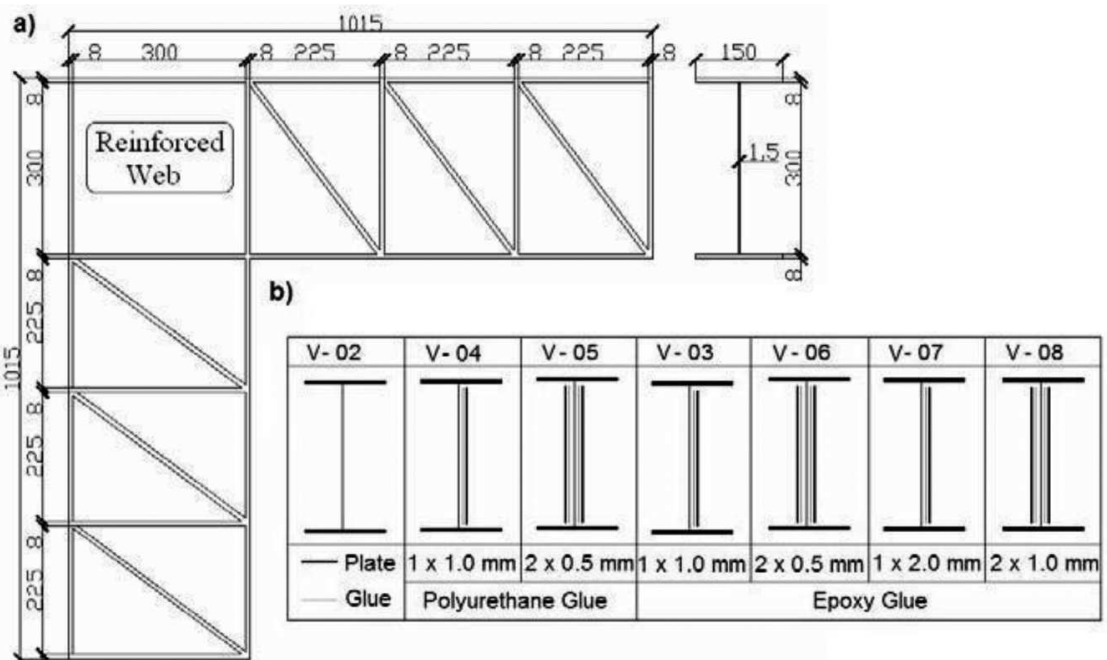

Fig. 15. Geometry and layouts of reinforcements of the knee joint, [5], [21].

The following are some examples of successful use of adhesive to strengthen girders: a knee of a girder frame Pasternak, Schwarzlos, Schimmach [10] and a slender box girder KuBIENIEC [3].

Fig. 15 shows the geometry of the tested frame knee (a) and the methods of knee strengthening which differ in the number of added plates and the type of adhesive (b).

The increase in the bending moment capacity from $44 \%$ to $53 \%$ reached in the tests for the non-strengthened knee (V-02) and for the strengthened models (V-03 to $\mathrm{V}-08$ ) shown in Fig. 15b is visible in the paths of equilibrium M- $\phi$ (bending moment - rotation angle) presented in Fig. 16. 

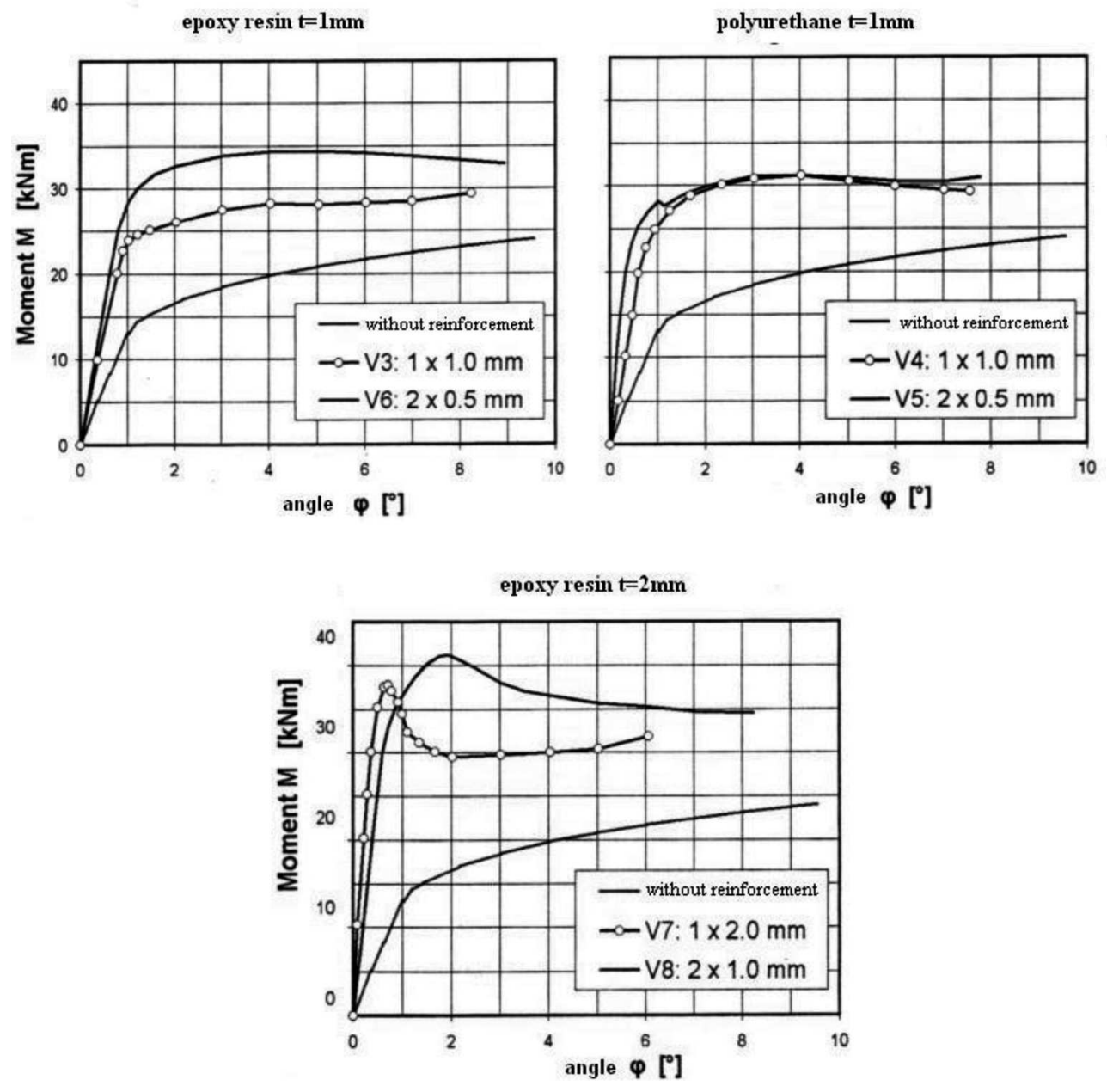

Fig. 16. Moment - rotation paths of equilibrium for the knee joint Pasternak, Kubieniec, Piekarczyk [5], [21].

Fig. 17 shows the geometry and the loading of the box girder with the strengthened web by two plates each $3 \mathrm{~mm}$ thick. The plates are joined to the web using an epoxy pre-polymer (Korapox 558 - see Table 1) of a $1 \mathrm{~mm}$ layer.

Fig. 18 presents the load $(\mathrm{P})$ - deflection (u) paths of equilibrium for the strengthened and non-strengthened beams. A distinct increase (about 60\%) of bending capacity of beams in the case of reinforced girder was noticed.

Adhesive technique of joining can be also a serious alternative in the case of assembly connections of girders. A concept of an adhesively bonded universal connection was presented in, Kubieniec, Piekarczyk [20]. A design method and its verification 


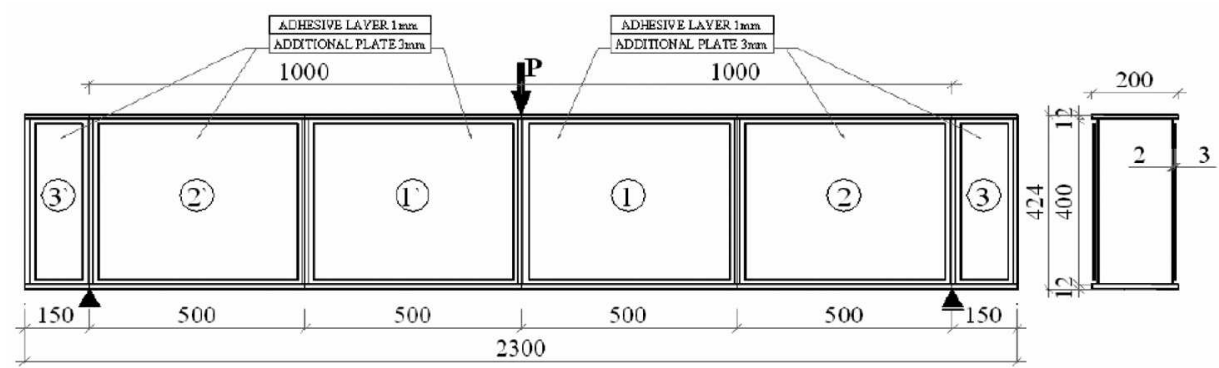

Fig. 17. Geometry and layouts of reinforcements of the box girder Pasternak, Kubieniec, Piekarczyk [5], [21].

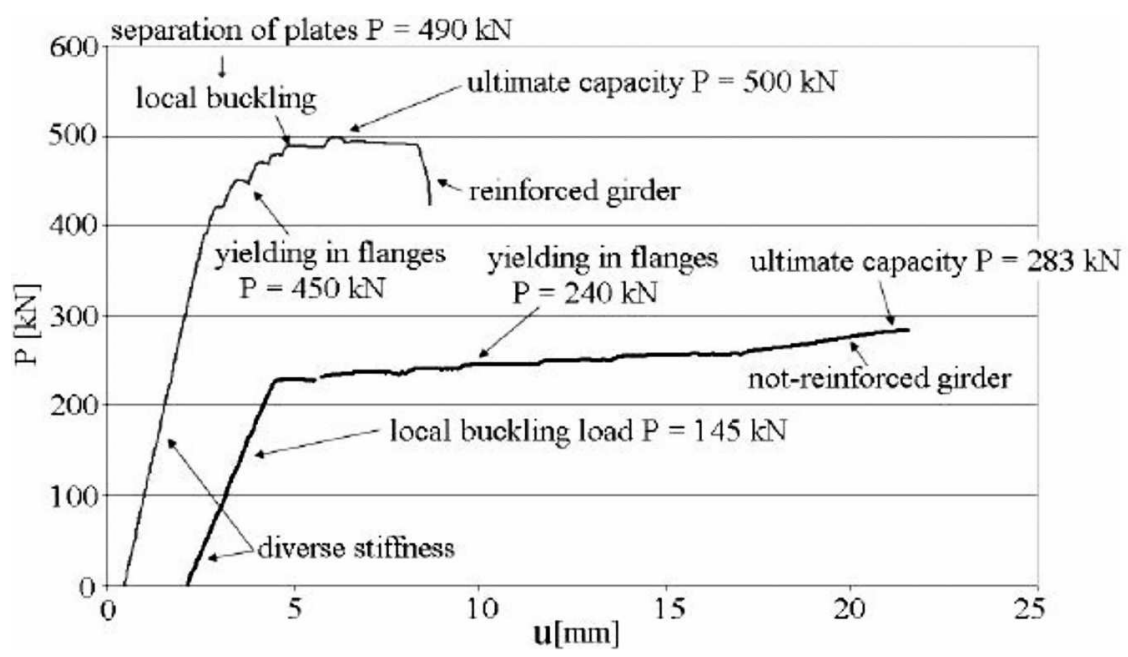

Fig. 18. Comparison of experimental $\mathrm{P}-\mathrm{u}$ paths of equilibrium of the reinforced and not reinforced box girders Pasternak, Kubieniec, Piekarczyk [5], [21].

by numerical calculations was shown there. A development of the solution, however, would require further experimental studies.

\subsection{Cellular beam systems and systems SPS (steel-Polymer-STeel)}

Openwork steel panels are an alternative to conventionally welded orthotropic panels as they eliminate fatigue resulting from welding and decrease depth of the cross section without reduction of bending capacity due to additional glued bottom plate.

Some glued openwork steel panels of different sections joined with thin (a) and thick (b) adhesive layers are presented in Fig. 19, Feldman, Volling, Ge $\beta$ Ler, WelLERSHOFF, Gei $\beta$, WaGNER [8]. The panels have shown high capacity, high isotropy and torsion rigidity in tests. 


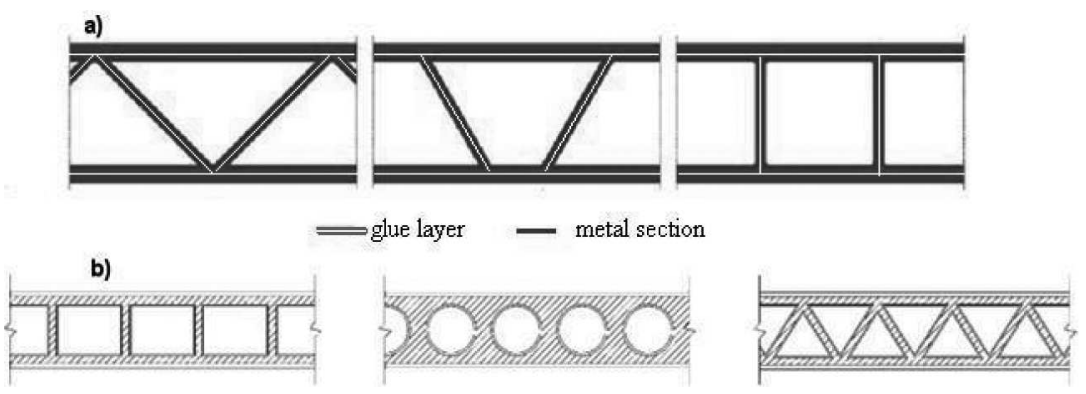

Fig. 19. Different cross-sections of hollow plates with thin (a) and thick (b) layers Feldman, Voluing, Ge $\beta$ Ler, Wellershoff, Gei $\beta$, Wagner [8].

SPS (steel-polymer-steel) panels are produced in sandwich technology with double sheet and elastomer joined adhesively to steel. This technology has been derived from shipbuilding and adapted for bridge construction at the Technical University in AachEN, Feldman, Volling, Ge $\beta$ Ler, Wellershoff, Gei $\beta$, Wagner [8].

An example of SPS panel taken from shipbuilding industry is shown in Fig. 20 (top), whereas bottom left is a traditional stiffened panel and bottom right an alternative glued panel recommended to use in bridges.

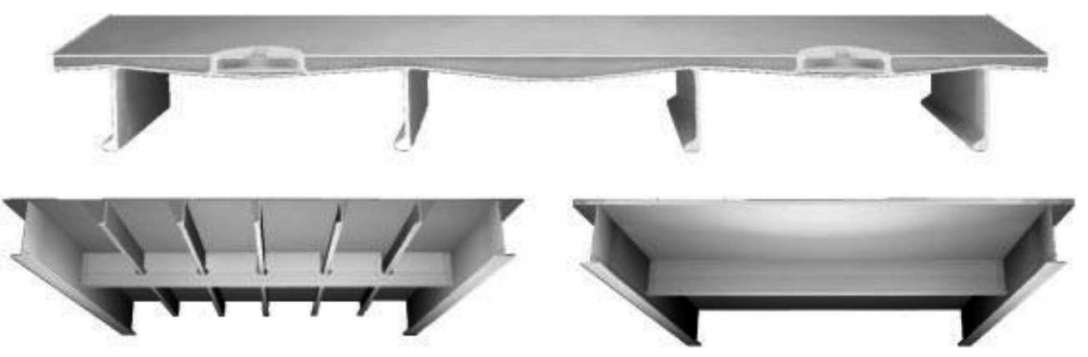

Fig. 20. Examples for the use of SPS - structures from shipbuilding (above) and bridge construction (bottom right, bottom left - conventional solution), Feldman, Volling, Ge $\beta$ Ler, Wellershoff, Gei $\beta$, WAGNER [8].

\subsection{Special aluminium applications}

Adhesively bonded aluminium alloys are very often used to diminish the weight of structures. An example of this application is Aston Martin V12 Vanquish motor car, HiLl [26]. Its structure is made of aluminium extrusions of various alloys and joined by adhesive bonding (Fig. 21).

Another example are Audi cars [51] whose body is also bonded in this way. An example in the aerospace industry are Boeing aircrafts whose parts such as stringers, 
straps, body skin of jet structure are adhesively bonded of aluminium parts (Fig. 22) [25]. Aluminium wing spars are also joined by adhesives [52].

As for the use of adhesive bonding in building structures one could quote façade panels connected to the structure by adhesive tapes produced by $3 \mathrm{M}$ company, see Fig. 23, [27].

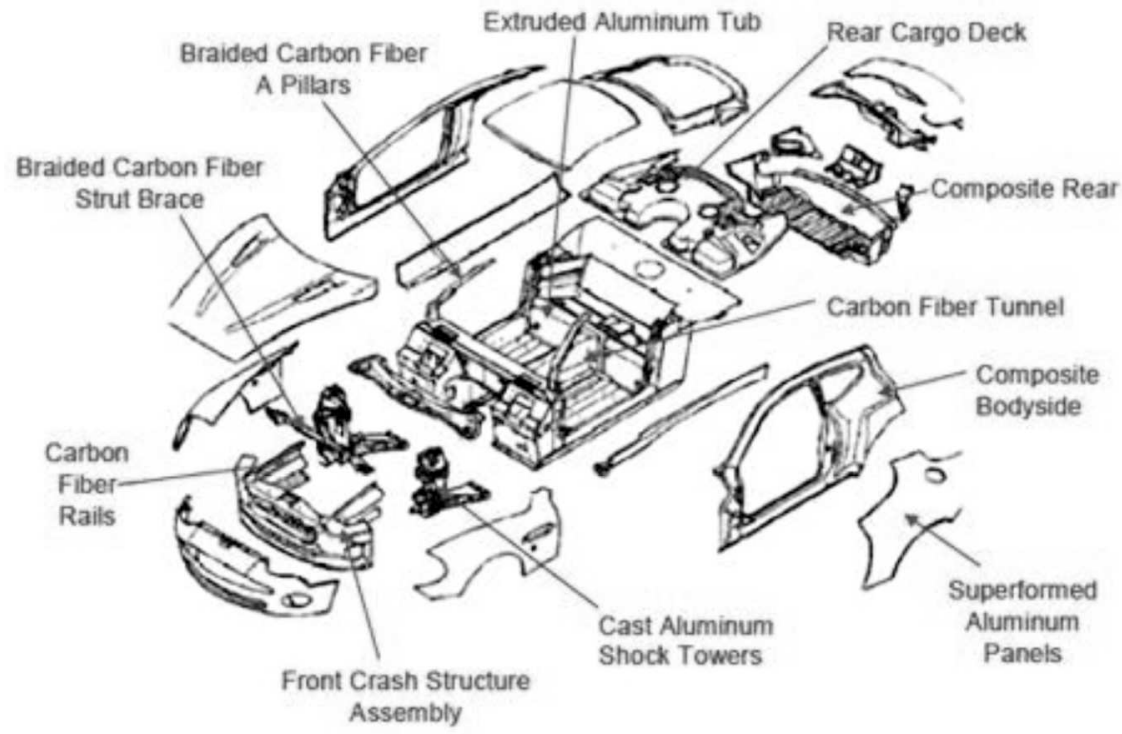

Fig. 21. Aston Martin V12 Vanquish, HiLl [26].
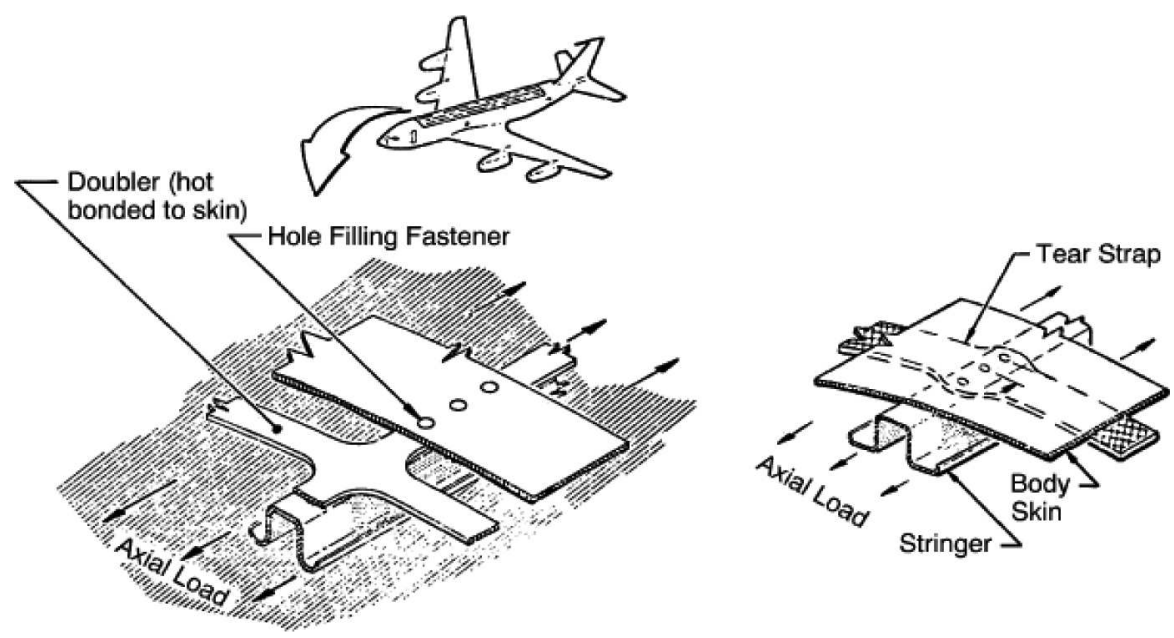

Fig. 22. A Boeing airliner [25]. 

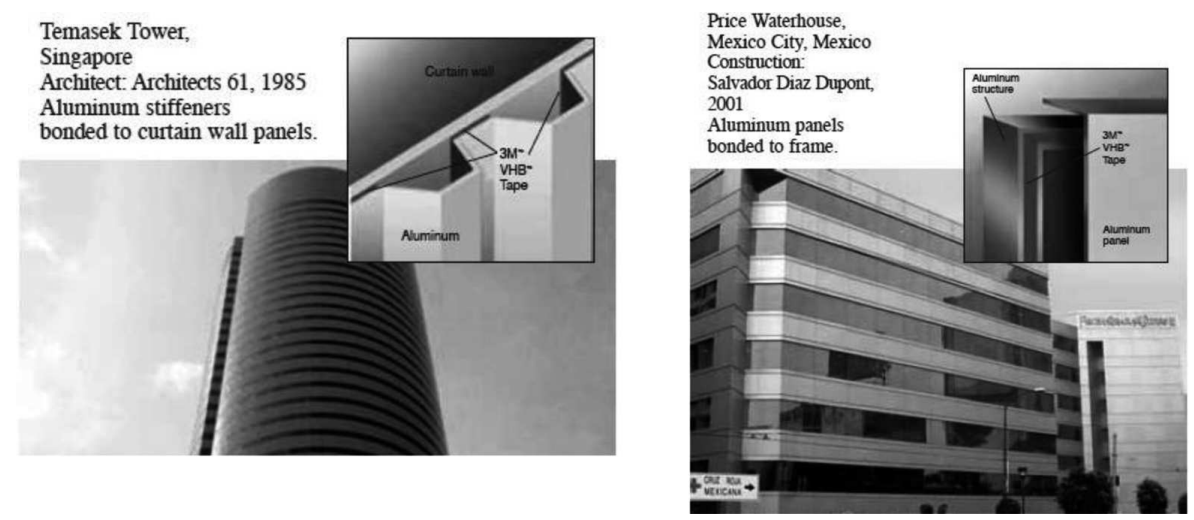

Fig. 23. Architectural panels [27].

\section{Conclusions}

The summary shall indicate the advantages of adhesive connections and limits of their application. The favourable characteristics of the connections are: even distribution of stresses in the connection, bearing loads by the whole joined area, absence of thermal stresses, possibility to connect different metals and metal with non-metal, surface protection against bimetallic and environmental corrosion, no disarrangement of the structure in connected elements, increasing stiffness of connections, lightness of connections in comparison with other methods.

The restriction of application of adhesive connections results mainly from their moderate resistance to high temperature (approx. more than $250^{\circ} \mathrm{C}$ ), impairment of some characteristics due to ageing, necessity of intensive pre-treatment, special care needed to fulfil demanding technological requirements, limited use of non-destructive tests in control.

Despite these restrictions, as it is shown particularly in Chapter 5, adhesive bonding has become a serious alternative for traditional methods of joining elements in steel and aluminium structures i.e. connecting them with bolts or welding.

\section{REFERENCES}

1. D.A. Dillard, Advances in Structural Adhesive Bonding, Woodhead Publishing Limited, Oxford, Cambridge, New Delhi, 2010.

2. J. Meinz, Adhering in Steel Structures. Considerations on Carrying-Capacity and Deformations and on Dimensioning of Adhesively Bonded Trapezoidal Sheets as Well as Strengthened Hollow Profiles in Beam-Column-Façades [in German], Weißensee Verlag, 2010, Dissertation, BTU Cottbus. 
3. G. KubIEnIEc, Resistance of Reinforced Steel Girders with Adhesive Bonding [in Polish], PhD thesis, Cracow University of Technology, 2008.

4. G. Kubieniec, M. Piekarczyк, Thin-Walled Steel Griders Reinforced with Use of Adhesives - Experimental and Numerical Investigation, Eurosteel 2008 Conference, $3^{\text {rd }}$ to $5^{\text {th }}$ September 2008, Graz, Austria, 1611-1616.

5. H. Pasternak, G. Kubieniec, M. Piekarczyk, Adhesives in Strengthening of Steel Structures, Proceedings of PROHITECH 09, Protection of Historical Buildings, ed. Mazzolani, 2009 Taylor\&Francis Group, London, 551-556.

6. H. Pasternak, J. Meinz, Investigation of Adhesive Reinforcements in Steel Building Structures [in German], Bauingenieur, 81, 212-217, May 2006.

7. K. Dilger, M. Feldman, P.L. Gei $\beta$, H. Pasternak, T. Ummenhofer, et al., Research for Practice P654 [in German], New Constructions Due to Application of Adhesive Bonding in Steel Structures, FOSTA, Düsseldorf 2008.

8. M. Feldman, B. Völling, A. Ge $\beta$ ler, F. Wellershoff, P. Gei $\beta$, A. Wagner, Adhesive Bonding for Steel Construction, Stahlbau 75 (2006), Copybook 10, 834-846 [in German].

9. P.A. KróL, Analysis of Bearing Capacity and Deformability Adhesive, Bolted and Adhesive-Bolted Lap Joints in Sheet Metal Structures [in Polish], PhD thesis, Warsaw University of Technology, Warsaw 2007.

10. H. Pasternak, A. Schwarzlos, N. Schimmach, The Application of Adhesives to Connect Steel Members, Journal of Constructional Steel Research 60, 649-658, 2004.

11. M. Cwyl, Adhesively Bonded Connections of Glass Elements and Metal Frame [in Polish], PhD thesis, Warsaw University of Technology, Warsaw 2007.

12. K. Machalicka, M. Eliasova, Glued Connection in Glass Structures. Influence of Different Factors to Shear Load Carrying =- capacity, Eurosteel 2011, Budapest, Hungary, 387-392.

13. H. Pasternak, J. Meinz, Adhering in Steel Construction - Two Examples in Façades Construction [in German], Bauingenieur, 82, 115-124, March 2007.

14. J. Godzimirski, S. Tkaczuk, Definition of Mechanical Properties of Adhesive Connections [in Polish], Technologia i Automatyzacja Montażu, 3-4, 2004.

15. J. Godzimirski, S. Tкасzuк, Numerical Modelling of Shear Adhesive Connections [in Polish], Bulletin MUT, 4/2005, 2005.

16. J. Godzimirski, A. Koмоreк, Examinations of Fatigue Durability of Plastics and Adhesive Connections [in Polish], Czasopismo Techniczne M., z.6-M, 201-206, 2006.

17. J. Godzimirski, M. Rośкоwicz, Creeping of Plastics and Adhesive Connections [in Polish], Czasopismo Techniczne M., z.6-M, 207-214, 2006.

18. M. Lagoda, Bridge Reinforcement by Gluing Elements, Monograph 322, Cracow University of Technology, Cracow 2005.

19. W. ŻóŁtowsкi, M. Cwyl, P.A. KróL, Analysis of Connections Between Glass and Metal Based on Structural Silicone, IMCS 2006, Rzeszów, Poland, 21-23 June 2006.

20. G. Kubieniec, M. Piekarczyk, Adhesively Bonded Assembly Connection [in Polish], Zeszyty Naukowe Politechniki Rzeszowskiej. Budownictwo i inżynieria środowiska 2.50, 165-174, 2008.

21. H. Pasternak, G. Kubieniec, M. Piekarczyk, Adhesives in Strengthening of Steel Structures, Engineering Structures and Technologies, 2(2), 45-50, 2010.

22. W. Gıodkowska, M. Ruchwa, Static Analysis of Reinforced Concrete Beams Strengthened with CFRP Composites, Archives of Civil Engineering, 56, 2, 111-122, 2010.

23. T. Urban, J. Tarka, Strengthening of Slab-Column Connections with CFRP Strips, Archives of Civil Engineering, 56, 2, 193-212, 2010.

24. A. Peiris, I. Harik, Field Testing of Steel Bridge Girders Strengthened Using Ultra High Modulus (UHM) Carbon Fiber Reinforced Polymer (CFRP) Laminates, The $6^{\text {th }}$ International Conference on FRP Composites in Civil Engineering, 13-15 June 2012, Rome, Conference Proceedings. 
25. www.boeing.com, Boeing Design Manual BDM-1440.

26. J. Hill, Adhesively Bonded Structural Composites for Aston Martin Vehicles, Ford Motor Company Research and Advanced Engineering.

27. www.3M.com, 3M Design Guide for Architectural Metal Panels.

28. PROXIMA NTR Sp. z o. o.: Industry Adhesives - Manual, 2006 [in Polish].

29. Megachemie, www.megachemie.com

30. PN-69/C-89300, Adhesives for Metal, Determination of Shear Strength [in Polish].

31. DIN EN ISO/DIS 11003-2 - Adhesives, Determination of Shear Characteristics for Structural Adhesives, Part 2, Shear tests for Thick Glue Joints, December 2001 [in German].

32. PN-81/C-89034, Plastics, Determination of Properties in Static Tensile Strength [in Polish].

33. DIN EN 26922 - Adhesives, Determination of Tension Characteristics for Bevelled Adhesive Joints, May 1993 [in German].

34. www.ntr.com.pl.

35. M. Czarnormska, Influence of Ageing on Capacity of Adhesively Bonded Metal Connections [in Polish], PhD thesis, Warsaw University of Technology, Warsaw 1987.

36. T. Hop, Layer Structures [in Polish], Arkady, Warsaw 1980.

37. O. Volkersen, New Decomposition of Force in Tensile of Straps with Cross Sections [in German], Luftfahrtforschung 15, 41-47, 1938.

38. M.Y. Tsai, D.W. Oplinger, J. Morton, Improved Theoretical Solution for Adhesives Lap Joints, Int. J. Solids Structures, 35, 12, 1163-1185, 1998.

39. M. Goland, E. Reissner, The Stresses in Cemented Joints, Journal of Applied Mechanics 11, A17-A27, 1944.

40. H. Kim, K. Kedward, U.S. Department of Transportation. Federal Aviation Administration: Stress Analysis of In-Plane, Shear Loaded, Adhesively Bonded Composite Joints and Assemblies, Final Report DOT/FAA/AR-01/7, April 2001.

41. L.J. Hart-Smith, Adhesive - Bonded Scarf and Stepped Lap - Joints, Technical Report No CR-112237, NASA, Longley Research Center, 1973.

42. N.A. DE Brugne, The Strength of Glued Joints, Aircraft Engineering, 16, 115-118, 1944.

43. L.J. Hart-Smith, Adhesive Bounded Double - Lap Joints, NASA No CR-112235, 1973.

44. M. Davis, D. Bond, Principles and Practices of Adhesive Bonded Structural Joints and Repairs, International Journal of Adhesion and Adhesives 19, 91-105, 1999.

45. H. Pasternak, J. Ciupak, Eurocode - Based Design Rules for Adhesive Bonded Joints, $6^{\text {th }}$ European Conference on Steel and Composite Structures, August 31 - September 2, 2011, Budapest, 717-722.

46. J.L. Clarke (edited by), Structural Design of Polymer Composites - EUROCOMP Design Code and Handbook, First Edition, Halcrow Polymerics Ltd., Great Britain, 1996.

47. Guideline for European Technical Approval for Structural Sealant Glazing Systems (SSGS): Part 1; Supported and Unsupported Systems, November 1999.

48. Deutsches Institut für Bautechnik: Approval No Z-14.1 - 4 for Connecting Elements in Connections of Building Structures in Light Metal Constructions, September 2005 (IFBS - Info 7.01) [in German].

49. G. Habenicht, Glues, Bases, Technologies, Application [in German], Springer Verlag, Berlin 2002.

50. Merkblatt 382: Adhesive Bonding of Steel and Rustless Steel, Stahl - Informations - Zentrum 1998 [in German].

51. www.audi.com.

52. www.permabond.com.

Remarks on the paper should be sent to the Editorial Office no later than December 31, 2012
Received April 19, 2012 revised version August 15, 2012 